\title{
Recreational Drug Use in People Living with HIV in Spain: Factors Associated with Drug Use and the Impact on Clinical Outcomes
}

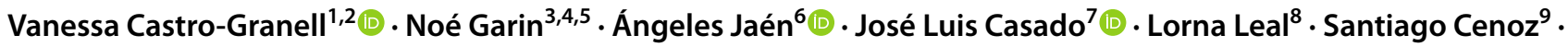 \\ María José Fuster-RuizdeApodaca ${ }^{10,11}$
}

Accepted: 16 April 2021 / Published online: 1 May 2021

(c) The Author(s) 2021

\begin{abstract}
We analysed the impact of recreational drug use (RDU) on different outcomes in people living with HIV (PLHIV). A multicentre retrospective cohort study was performed with two cohorts of PLHIV included: people using recreational drugs (PURD) vs. people not using recreational drugs (PNURD). Overall, 275 PLHIV were included. RDU was associated with men having sex with men (OR 4.14, 95\% CI [1.14, 5.19]), previous sexually transmitted infections (OR 4.00, 95\% CI [1.97, 8.13]), and current smoking (OR 2.74, 95\% CI [1.44, 5.19]). While the $\mathrm{CD}_{4} / \mathrm{CD}_{8}$ ratio increased amongst PNURD during the follow-up year, it decreased amongst PURD $(p=0.050)$. PURD presented lower scores of self-reported and multi-interval antiretroviral adherence $(p=0.017$, and $p=0.006$, respectively), emotional well-being $(p<0.0001)$, and regular follow-up $(p=0.059)$, but paid more visits to the emergency unit $(p=0.046)$. RDU worsens clinical, immunological, and mental health outcomes amongst PLHIV.
\end{abstract}

Keywords HIV $\cdot$ Recreational drug use $\cdot$ Antiretroviral therapy $\cdot$ Clinical outcomes

\section{Resumen}

Analizamos el impacto del consumo de drogas recreativas sobre variables relacionadas con la salud en personas con VIH (PVIH). Estudio multicéntrico retrospectivo con dos cohortes de PVIH: consumidores de drogas recreativas (CDR) y no consumidores (NCDR). Se incluyeron $275 \mathrm{PVIH}$. El consumo de drogas recreativas se asoció al colectivo de hombres que mantienen sexo con hombres (OR 4.14, IC95\% [1.14, 5.19]), a infecciones de transmisión sexual previas (OR =4.00, IC95\%

Vanessa Castro-Granell and María José Fuster-RuizdeApodaca contributed equally to this work.

Vanessa Castro-Granell

vanemcg@hotmail.com; castro_van@gva.es

Ángeles Jaén

ajaen@mutuaterrassa.es

http://www.mutuaterrassa.cat/fundaciorecerca/

María José Fuster-RuizdeApodaca

mjfuster@psi.uned.es

1 Doctoral Programme in Pharmacy, Granada University, Granada, Spain

2 Department of Pharmacy, Hospital Marina Baixa, Av. Alcalde En Jaume Botella Mayor, 7, 03570 Villajoyosa, Alicante, Spain

3 Department of Pharmacy, Hospital Santa Creu i Sant Pau, Universitat Autònoma de Barcelona, Barcelona, Spain

4 Instituto de Salud Carlos III, Centro de Investigación Biomédica en Red de Salud Mental (CIBERSAM), Madrid, Spain
5 School of Health Science Blanquerna, Universitat Ramon Llull, Barcelona, Spain

6 Research Unit, Fundació Docència i Recerca mutua Terrassa. Universidad de Barcelona, Terrassa, Barcelona, Spain

7 Department of Infectious Diseases, Hospital Ramón y Cajal, Madrid, Spain

8 Infectious Diseases-HIV Unit, Hospital Clínic Barcelona- IDIBAPS, Barcelona, Spain

9 Medical Department, ViiV Healthcare, Tres Cantos, Madrid, Spain

10 Spanish Interdisciplinary AIDS Society (Sociedad Española Interdisciplinaria del Sida, SEISIDA), Madrid, Spain

11 Department of Social and Organizational Psychology, Universidad Nacional de Educación a Distancia (UNED), Madrid, Spain 
$[1.97,8.13])$ y a ser fumador ( $\mathrm{OR}=2.74, \mathrm{IC} 95 \%[1.44,5.19])$. El ratio $\mathrm{CD}_{4} / \mathrm{CD}_{8}$ aumentó entre los $\mathrm{NCDR}$ durante el año de seguimiento y disminuyó en los CDR $(\mathrm{p}=0.050)$. Los CDR presentaron peor adherencia al tratamiento antiretroviral medida con dos métodos indirectos $(\mathrm{p}=0.017 \mathrm{y} \mathrm{p}=0.006$, respectivamente), y bienestar emocional $(\mathrm{p}<0.0001)$. Además, visitaron menos al especialista en enfermedades infecciosas $(p=0.059)$, y más a urgencias $(p=0.046)$. El consumo de drogas recreativas empeora los resultados clínicos y de salud mental entre las PVIH.

Palabras clave VIH · Drogas recreativas · Terapia antiretroviral $\cdot$ Resultados clínicos

$\begin{array}{ll}\text { Abbreviations } \\ \text { AIDS } & \text { Acquired immunodeficiency syndrome } \\ \text { ART } & \text { Antiretroviral therapy } \\ \text { HIV } & \text { Human immunodeficiency virus } \\ \text { HTX } & \text { Heterosexual } \\ \text { MSM } & \text { Men who have sex with men } \\ \text { PLHIV } & \text { People living with HIV } \\ \text { PWID } & \text { People who inject drugs } \\ \text { STIs } & \text { Sexually transmitted infections } \\ \text { RDU } & \text { Recreational drug use } \\ \text { PURD } & \text { People who use recreational drugs } \\ \text { PNURD } & \text { People who do not use recreational drugs }\end{array}$

\section{Background}

Advances in knowledge of HIV infection, as well as the emergence of new therapies, have revolutionised the natural history of the infection, which is currently considered a chronic disease with mortality rates similar to those of the general population [1]. This paradigm shift requires the adaptation of approaches to other emerging problems that can have a decisive impact on the management of HIV, including the prevalence of recreational drug use (RDU) which has potential implications for people living with HIV (PLHIV) in Spain [2, 3].

The pattern of illicit drug use in Spain has changed over time in terms of the substances consumed, the scenarios in which they are used, and user profiles. As a result, its impact on people and society as a whole has also changed [4]. People who injected drugs (PWID) in the 1980s and 1990s were often socially marginalised, and had a tenuous connection with the health system [5]. The prevalence of this profile has decreased from 1994 to 2010, reducing from 3.26 to 0.49 PWID per 1000 inhabitants, thanks to the implementation of specific harm reduction policies [6]. In return, the prevalence of drug use in the ludic or recreational environment has increased by about $50 \%$ amongst PLHIV, as studies conducted in Spain and elsewhere in Europe have shown [3, 7-11]. These have placed special emphasis on "polyconsumption," which is especially predominant in men who have sex with men (MSM) with HIV $[12,13]$.

The literature shows considerable variability in the frequency of use of different illicit drugs [3, 7-10]. According to the largest study conducted in Spain [3], there were four consumption patterns. Two were composed mostly of heterosexuals (HTX), and the other two principally of MSM. Amongst these studies were two well-differentiated polyconsumption profiles: a group of MSM (whose profile was related to recreational drug use) with the highest rate of polyconsumption, who showed an association with an increased risk of sexually transmitted infections (STIs), and a group of predominantly heterosexual (HTX) individuals (whose profile was associated with the use of traditional drugs such as heroin), who showed worse adherence to antiretroviral treatment (ART) and suffered worse health outcomes. The other two remaining groups presented a pattern of moderate drug use regarding both the frequency and diversity of drugs used. As for the clinical impact of illicit drug use, it seems that the pattern associated with PWID presents clear evidence of poor health outcomes [14-17]. However, interest in recreational drugs is relatively recent and less well known in the field of HIV. Studies have focused primarily on the risk of transmission of infectious diseases, mainly STIs, caused by a higher prevalence of risk behaviours associated with consumption [5, 18-26].

Some data suggest that the use of illicit drugs is predictive of poorer HIV outcomes, although the literature shows inconsistent findings [27]. Few studies have analysed the impact of recreational drug use on immunological parameters $\left(\mathrm{CD}_{4}, \mathrm{CD}_{8}\right.$, and $\mathrm{CD}_{4} / \mathrm{CD}_{8}$ ratio), but there are crosssectional studies that used self-reported data [28]. Chao et al. did not find evidence that the use of recreational drugs adversely affects $\mathrm{CD}_{4}$ or $\mathrm{CD}_{8} \mathrm{~T}$ cell counts in PLHIV, but they did not report polydrug use [27]. Moreover, several studies have focused on the study of traditional drugs (cocaine, heroin, and crack), and have found contradictory results [29-31]. It is difficult to determine the effect of illicit drug use on $\mathrm{CD}_{4}$ and $\mathrm{CD}_{8}$ cell count levels. Several factors could influence these cell counts, and there is no consensus in the literature about it. Such factors include the nadir $\mathrm{CD}_{4}$ [31], time on antiretroviral therapy [31], adherence level [29, 31], changes in ART [32], age [33], type of ART regimen [29], follow-up time [27], history of STIs [27], and smoking [27], among others. Thus, the impact of polyconsumption of recreational drugs on $\mathrm{CD}_{4}$ and $\mathrm{CD}_{8}$ counts remains unclear.

Besides immunological parameters, illicit drug use could have an impact on other health-related variables. Studies show that RDU can have a negative impact on adherence to 
ART $[9,26,34,35]$. However, the results have been variable and controversial [5, 11, 36-41]. The relationship between RDU and the lack of adherence is complex, and includes intentional and unintentional mechanisms. Adherence is closely linked to viral suppression and is therefore considered a clear predictor of ART success and survival [42]. However, the clinical relevance of the impact of adherence on health in PLHIV using recreational drugs remains uncertain. In fact, some studies suggest that RDU in PLHIV does not affect the viral load level $[42,43]$. Certain factors might modulate the final impact of adherence on health outcomes; on the one hand, less restrictive adherence cut-off points (around 80-90\%) [44], which achieve viral suppression and, on the other hand, the use of simplified ART regimes [45].

Recreational drug use also has an impact on mental health, although it is difficult to establish causality or directionality because they co-occur very frequently [46]. The negative impact of opioid and stimulant use (including methamphetamines) on the mental health dimension of quality of life [47] has been investigated, and it has been found that their use is associated with increased anxiety, depression, and psychosis [48]. Also, anxiety and depression are particularly prevalent in MSM, and there is a strong association with drug use [49]. Both are associated with risky sexual practices, the increased risk of HIV transmission, and the more frequent use of medical services [50-52].

RDU can also have consequences for the health economy. Some authors claim that the situation may deteriorate because of increased hospitalisations and visits to outpatient and emergency centres [52,53], dose increases or changes in prescription, or the performance of greater numbers of more invasive diagnostic tests [54]. To the best of our knowledge, no Spanish studies have examined this issue in PLHIV.

Thus, it appears that existing evidence of the impact of RDU on variables related to physical and psychological health is limited; most of the studies are cross-sectional, while the majority focus on the increased risk of STIs, are aimed at the study of traditional drugs and report limited data about the impact of polyconsumption on clinical markers. Thus, the present study, through a retrospective cohort design, had the main objective of examining the impact of recreational drug polyconsumption on several health-related variables in a PLHIV cohort in Spain. It specifically aimed to explore: (1) the variables associated with RDU; (2) potential differences in health outcomes between PLHIV people using recreational drugs (PURD) and people not using recreational drugs (PNURD), including their immunological status evolution during the follow-up period; and (3) potential differences in their use of healthcare services and resources.

\section{Method}

\section{Design and Sample}

The present study is a part of a broader research project that aimed to analyse several aspects of the use of illicit drugs amongst PLHIV in Spain. We previously conducted a qualitative study interviewing 21 PLHIV who used illicit drugs [2], and a second observational cross-sectional ex-post facto study with 1401 PLHIV [3]. The current third study comprised multicentre observational, retrospective cohort research, in which two cohorts of PLHIV were formed: PURD and PNURD.

We estimated a minimum required sample of 222 PLHIV, with 111 in each group (i.e., PURD and PNURD), accepting an alpha risk of 0.05 and a beta risk of 0.2 in a bilateral contrast (and considering a follow-up loss rate of 10\%); the aim was to achieve an expected standardised mean difference in ART adherence of the PURD group of 0.395, based on the results of the meta-analysis by Langebeek et al. [55]. This sample size was sufficient to detect small-to-moderate effect size differences in the other variables under investigation. Due to the fact that we have several outcome variables, we chose ART adherence to estimate sample size; there is more scientific evidence as to what the expected differences between groups would be.

The general inclusion criteria for both groups were HIV positive diagnosis, age over 18 years, taking ART for at least one year, clinical follow-up of more than 1 year at the centre, and not having any severe psychiatric or cognitive disorder. The specific inclusion criteria for the two cohorts were: PURD (consumption $\geq$ one drug $\geq 10$ times a year, excluding the use of cannabis as a single drug) vs. PNURD (including the consumption of cannabis $\leq 10$ times a year). The exclusion criteria for both groups were the consumption of methadone or heroin and dependence on alcohol (current or in the previous 5 years) (Fig. 1).

\section{Procedure}

Data from the study participants were collected from four University Hospitals in three of the most populous Spanish regions (Madrid, Barcelona, and Alicante) between April 2017 and May 2018. Two cohorts of PLHIV were recruited according to the inclusion and exclusion criteria for each group (PURD vs. PNURD) during regular clinical visits. Healthcare providers explained the study's goals to the participants, requesting their participation and obtained their informed consent. In the same clinical visit, participants responded to a cross-sectional online survey containing the self-reported variables. The survey was self-administered with the support of tablet computers. 
Fig. 1 Cohorts of participants, inclusion and exclusion criteria. $P U R D$ people using recreational drugs, $P N U R D$ people not using recreational drugs

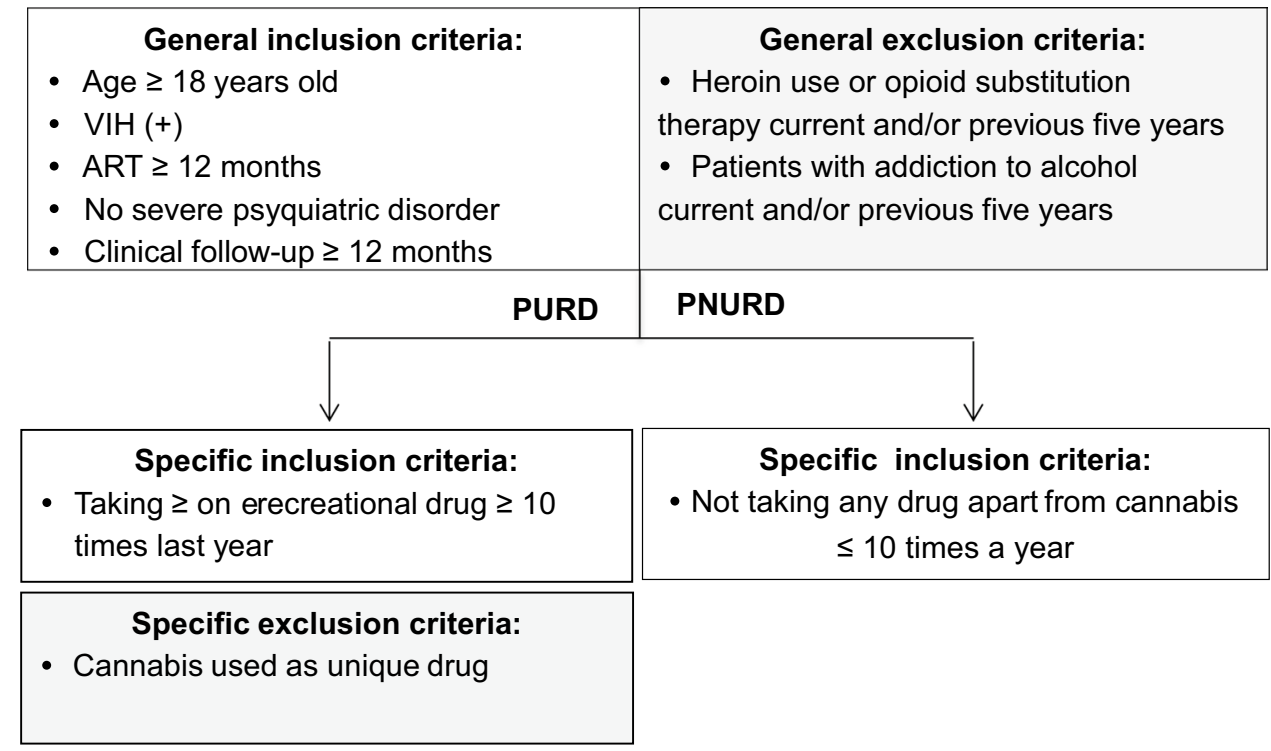

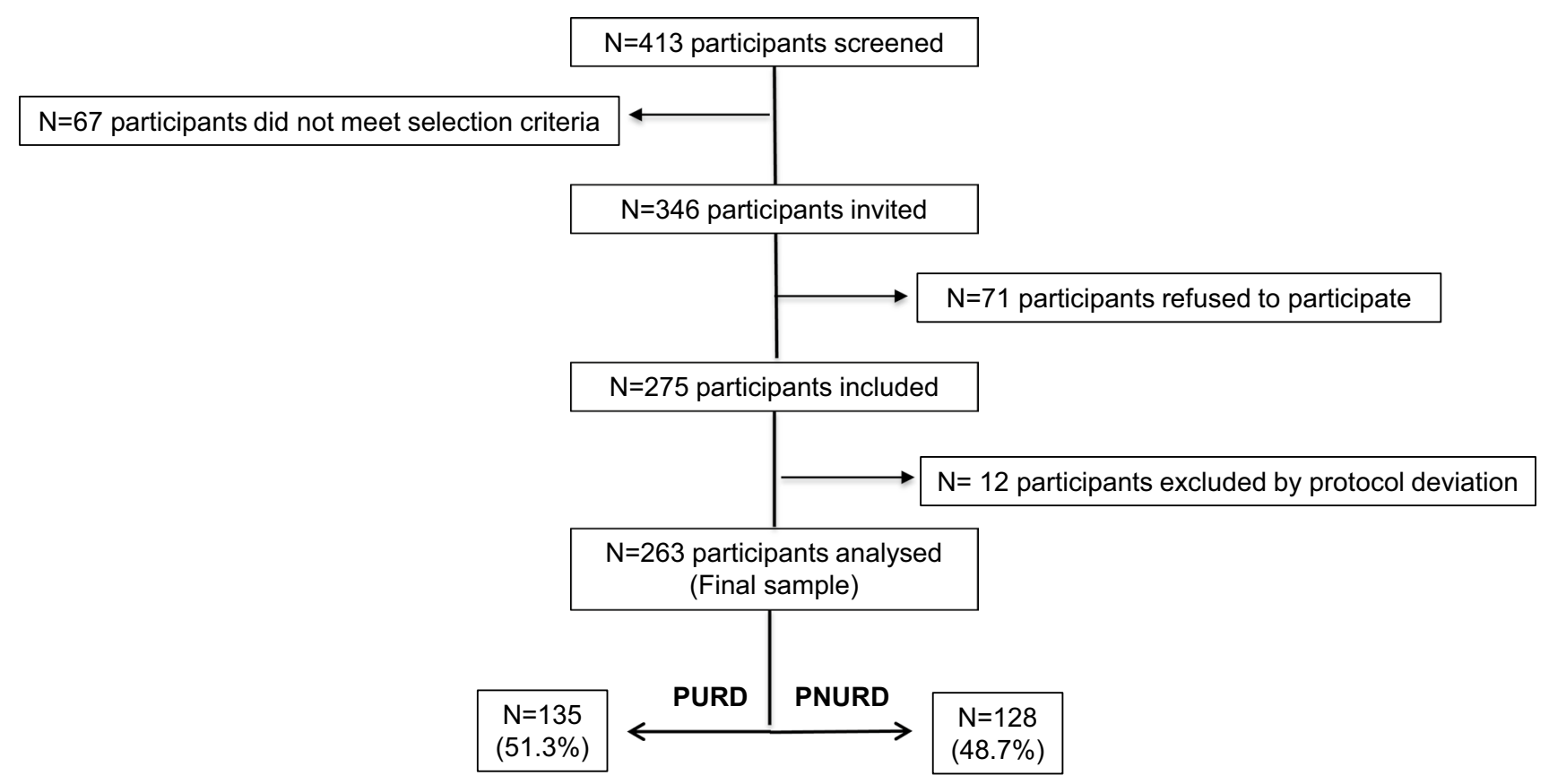

Fig. 2 Study sampling. PURD people using recreational drugs, $P N U R D$ people not using recreational drugs

Healthcare providers performed an initial screening of 413 patients during clinical visits. Of them, 67 did not fulfil the selection criteria. Among the remaining 346 patients, 71 refused to participate. Finally, 275 patients were included in the study after they signed the informed consent. The acceptance rate of participation in the study was $79.4 \%$. Out of the 275 PLHIV included in the study (146 PURD and 129 PNURD), 12 participants were excluded due to protocol deviation detected during depurating data. The final analysed sample $(N=263)$ was composed of 135 PURD $(51.3 \%)$ and 128 PNURD (48.7\%) (Fig. 2).

Next, the collaborating researchers collected retrospective clinical data of the previous 12 months from clinical records.

The Ethics Committee of the Hospital Clínico of Valencia approved the research protocol. Written informed consent was obtained from all participants. All of the procedures of the study followed the 1964 Declaration of Helsinki (revised in 1996), as well as the guidelines for good clinical practice. The Spanish AIDS 
multidisciplinary Society (SEISIDA) coordinated the study.

\section{Measures}

We collected the following retrospective last-12-month clinical data from clinical records: ART adherence (pharmacy refill), $\mathrm{CD}_{4}, \mathrm{CD}_{4} / \mathrm{CD}_{8}$ ratio, viral load, resistance to and adverse effects of ART, previous clinical conditions, clinical events in the last year, and the use of health services in the last year.

Participants responded to a cross-sectional online survey containing the patient-reported outcome measures. The procedures for designing the survey that was used are described in Fuster-RuizdeApodaca et al. [3]. Variables used in the present analysis were:

\section{Use of Illicit Drugs and Other Substances}

The survey included items that measured the type of illicit drugs used during the last year, and the frequency and route of consumption. A list of 18 illicit drugs was included.

\section{ART Adherence}

We used the Questionnaire to Evaluate the Adherence to HIV Therapy (CEAT-VIH) [3, 56]. Higher scores indicate higher treatment adherence.

\section{Psychological Well-Being}

We used the 12-item validated Spanish version of the General Health Questionnaire (GHQ-12). The higher the score, the worse the psychological health. Normative data in the Western population indicates that scores $>14$ in the GHQ-12 are indicative of poor psychological health $[57,58]$.

The survey also collected several socio-demographic characteristics: age, gender, sexual orientation, education level, employment status, financial resources, and city of residence.

\section{Data Analysis}

We carried out multivariate logistic regression to assess the socio-demographic/clinical factors associated with RDU. We selected the independent variables (covariates) based both on a theoretically based approach (see previous findings in the literature review) and significance at a level of $<0.1$ in the bivariate analysis. The categorical covariates included in the model were: sexual orientation (MSM vs. HTX), STIs in the previous year (yes/no), current smoking (yes/no), previous clinical conditions (yes/no), employment status (working vs. not working), and route of HIV transmission (sexual vs. another route). The continuous covariates included were age, level of education, years since HIV diagnosis, monthly incomes, and frequency of drinking alcohol.

Next, we used a linear mixed model for repeated measures over time to analyse the change between the first (baseline) and the last determination during the follow-up year using the following immunological parameters: percentage of $\mathrm{CD}_{4}$ and $\mathrm{CD}_{8}$ cells $/ \mathrm{mm}^{3}$ and $\mathrm{CD}_{4} / \mathrm{CD}_{8}$ ratio (withinsubject dependent variable) between PURD and PNURD (between-group factor). We included the following covariates in the model: age, time since HIV diagnosis, number or ART changes and ART adherence (pharmacy refill) during the follow-up year.

Finally, to examine the differences in other health-related variables collected once during the follow-up period, we used Student's $t$ or $\chi^{2}$, depending on the nature of the data. The analysis was also checked with non-parametric tests; we considered a $p$ value $<0.05$ to be significant. The analysis was performed using SPSS v.22 software.

\section{Results}

\section{Characteristics of the Participants}

Table 1 shows the socio-demographic, clinical, and epidemiological characteristics of the participants, and differences between PURD and PNURD. The PURD were single, employed, and living in urban areas mostly. They were younger, and had been diagnosed and taking ARV within a shorter time frame than the PNURD. They also contained a higher proportion of MSM.

The most prevalent recreational drugs consumed by the PURD were poppers, cocaine, and cannabis. The average number of different drugs used per participant in the last year was $5.5(S D=3.2$; range $1-14)$. Injected and rectal administration routes accounted for $10.4 \%$ and $9.6 \%$ of the cases, respectively (Table 2).

\section{Predictors of RDU}

The full logistic regression model containing the predictors was statistically significant, $\chi^{2}(d f=11, n=229$, $\mathrm{PURD}=114, \mathrm{PNURD}=115)=79.32, p<0.0001$, indicating that the model distinguished between PURD and PNURD. The model explained the following percentage of variance: $\mathrm{R}^{2}=0.29$ (Cox \& Snell), 0.390 (Nagelkerke), and 0.25 (Homer \& Lemeshow). Based on odds ratio or effect size, MSM compared with HTX, and those who had contracted STIs in the previous year compared with those who had not were around four times more likely to be PURD. Moreover, current smoking was a positive predictor, whereas age was 
Table 1 Differences between participants who used and who did not use recreational drugs in the variables under study

\begin{tabular}{|c|c|c|c|c|}
\hline & $\begin{array}{l}\text { Total } \\
(n=263)\end{array}$ & $\begin{array}{l}\text { PURD } \\
(n=135,51.3 \%)\end{array}$ & $\begin{array}{l}\text { PNURD } \\
(n=128,48.7 \%)\end{array}$ & $\begin{array}{l}p \text {-value } \\
\text { (Contrast statistic) }\end{array}$ \\
\hline \multicolumn{5}{|l|}{ Patients' characteristics } \\
\hline Age, mean ( $S D$; years) & $45.79(10.86)$ & $42.21(8.24)$ & $49.56(11.99)$ & $<0.0001(t=-5.76)$ \\
\hline Gender & & & & $0.003\left(\chi^{2}=11.45\right)$ \\
\hline Male, \% (n) & $93.5(246)$ & $98.5(133)$ & $88.3(113)$ & \\
\hline Female, $\%(n)$ & $6.1(16)$ & $1.5(2)$ & $10.9(14)$ & \\
\hline Transgender, $\%(n)$ & $0.4(1)$ & 0 & $0.8(1)$ & \\
\hline Sexual orientation & & & & $<0.0001\left(\chi^{2}=21.85\right)$ \\
\hline Heterosexual, \% (n) & $12.9(34)$ & $4.4(6)$ & $21.9(28)$ & \\
\hline Homosexual, \% (n) & 78.7 (207) & $89.6(121)$ & $67.2(86)$ & \\
\hline Bisexual, \% (n) & $5.7(15)$ & $3.7(5)$ & $7.8(10)$ & \\
\hline Others, \% (n) & $2.7(7)$ & $2.2(3)$ & $3.1(4)$ & \\
\hline Current relationship & & & & $0.034\left(\chi^{2}=4.48\right)$ \\
\hline Yes, \% (n) & $40.3(106)$ & $34.1(46)$ & $46.9(60)$ & \\
\hline No, $\%(n)$ & $59.7(57)$ & $65.9(89)$ & $53.1(68)$ & \\
\hline Educational level & & & & $0.080\left(\chi^{2}=6.77\right)$ \\
\hline No studies, \% (n) & $1.2(3)$ & 0 & $2.4(3)$ & \\
\hline Primary, \% (n) & $17.5(45)$ & $13.6(18)$ & $21.6(27)$ & \\
\hline Secondary, \% (n) & $41.6(107)$ & $42.4(56)$ & $10.8(51)$ & \\
\hline University degree, $\%(n)$ & $31.7(102)$ & $43.9(58)$ & $35.2(44)$ & \\
\hline Work situation & & & & $<0.0001\left(\chi^{2}=19.88\right)$ \\
\hline Working, \% (n) & $66.2(174)$ & $76.3(103)$ & $55.5(71)$ & \\
\hline Unemployed, \% (n) & $20.2(53)$ & $17.8(24)$ & $22.7(29)$ & \\
\hline Retired or disability, \% (n) & $12.5(33)$ & $4.4(6)$ & $21.1(27)$ & \\
\hline Other, \% (n) & $1.1(3)$ & $1.5(2)$ & $0.8(1)$ & \\
\hline Monthly income $^{\mathrm{a}}$ & $2.77 \pm 0.84$ & $2.66 \pm 0.82$ & $2.88 \pm .84$ & $0.035(t=-2.12)$ \\
\hline Residence & & & & $0.015\left(\chi^{2}=5.92\right)$ \\
\hline Rural $^{\mathrm{b}}, \%(n)$ & $4.6(12)$ & $1.5(2)$ & $7.8(10)$ & \\
\hline Urban, \% $(n)$ & $94.7(249)$ & $98.5(131)$ & $92.2(118)$ & $<0.0001(t=-5.76)$ \\
\hline \multicolumn{5}{|l|}{ HIV health-related variables } \\
\hline Time diagnosed, $M \pm S D$ (years) & $13.28 \pm 7.59$ & $11.70 \pm 5.78$ & $14.93 \pm 8.80$ & $0.001(t=-3.37)$ \\
\hline Time on ART, $M \pm S D$ (years) & $10.67 \pm 6.27$ & $9.92 \pm 5.66$ & $12.01 \pm 7.20$ & $0.014(t=-2.47)$ \\
\hline Previous clinical conditions, $\%(n)$ & $75.7(199)$ & $82(105)$ & $69.6(94)$ & $0.019\left(\chi^{2}=5.48\right)$ \\
\hline$M \pm S D$ & $2.56 \pm 1.80$ & $2.88 \pm 2.08$ & $2.20 \pm 1.35$ & $0.006(t=-2.76)$ \\
\hline Route of transmission & & & & $0.051\left(\chi^{2}=3.80\right)$ \\
\hline Sexual intercourse, \% (n) & $81.4(214)$ & $85.9(116)$ & $76.6(98)$ & \\
\hline Other routes, \% (n) & $18.6(49)$ & $14.1(19)$ & $23.4(30)$ & \\
\hline HIV stage, $\%(n)$ & & & & $0.005\left(\chi^{2}=21.87\right)$ \\
\hline A1 & $40.9(79)$ & $24(18)$ & $51.7(61)$ & \\
\hline A2 & $28(54)$ & $37.3(28)$ & $22(26)$ & \\
\hline $\mathrm{A} 3$ & $9.3(18)$ & $10.7(8)$ & $8.5(10)$ & \\
\hline B1 & $3.1(6)$ & $4(3)$ & $2.5(3)$ & \\
\hline B2 & $4.1(8)$ & $2.7(2)$ & $5.1(6)$ & \\
\hline B3 & $2.1(4)$ & $4(3)$ & $0.8(1)$ & \\
\hline $\mathrm{C} 1$ & $2.6(5)$ & $2.7(2)$ & $2.5(3)$ & \\
\hline $\mathrm{C} 2$ & $1(2)$ & 0 & $1.7(2)$ & \\
\hline $\mathrm{C} 3$ & $8.8(17)$ & $14.7(11)$ & $5.1(6)$ & \\
\hline STIs, \% (n) & $34.6(91)$ & $51.9(70)$ & $16.4(21)$ & $<0.0001\left(\chi^{2}=36.48\right)$ \\
\hline$M \pm S D$ & $1.89 \pm 1.02$ & $2.04 \pm 1.05$ & $1.38 \pm 0.74$ & $0.009(t=2.67)$ \\
\hline Current smoker, $\%(n)$ & $49.4(130)$ & $62.2(84)$ & $35.9(46)$ & $<0.0001\left(\chi^{2}=18.16\right)$ \\
\hline Frequency drinking alcohol ${ }^{\mathrm{c}}, M_{ \pm} S D$ & $3.98 \pm 1.83$ & $4.22 \pm 1.68$ & $3.73 \pm 1.95$ & $0.032(t=2.17)$ \\
\hline
\end{tabular}

PURD people using recreational drugs, $P N U R D$ people not using recreational drugs

${ }^{a}$ The item ranged from 1 (none); $2(\leq 1000 €) ; 3(1001-2000 €) ; 4(2001-6000 €)$ and $5(>6001 €)$ 
Table 1 (continued)

b "urban" if having more than 10,000 inhabitants

${ }^{\mathrm{c}}$ Frequency of drinking alcohol responses ranged from 1 (never); 2 (sometimes a year); 3 (once a month); 4 (sometimes a month); 5 (once a week); 6 (sometimes a week) and 7 (daily)

Table 2 Type and frequency of recreational drugs used and consumption routes

\begin{tabular}{|c|c|c|}
\hline Drugs & $\begin{array}{l}\%(\mathrm{~N}) \\
100(135)\end{array}$ & $\begin{array}{c}M \pm S D^{\mathrm{a}} \\
5.5 \pm 3.2\end{array}$ \\
\hline Poppers & $81.5(110)$ & $2.5 \pm 1.5$ \\
\hline Cocaine (powder) & $72.6(98)$ & $1.9 \pm 1.2$ \\
\hline Cannabis & $63.0(85)$ & $2.9 \pm 2.1$ \\
\hline GHB/GBL & $57.8(78)$ & $1.7 \pm 1.3$ \\
\hline MDMA (pills) & $50.4(68)$ & $1.5 \pm 0.8$ \\
\hline MDMA (crystal) & $45.9(62)$ & $1.4 \pm 0.7$ \\
\hline Ketamine & $40.7(55)$ & $1.4 \pm 1.0$ \\
\hline Mephedrone & $40.7(55)$ & $1.4 \pm 0.9$ \\
\hline Speed & $37.0(50)$ & $1.4 \pm 0.8$ \\
\hline Methamphetamine & $36.3(49)$ & $2.1 \pm 1.7$ \\
\hline Cocaine (base) & $5.9(8)$ & $2.1 \pm 1.6$ \\
\hline Spice drugs & $5.9(8)$ & $1.5 \pm 0.9$ \\
\hline LSD & $5.2(7)$ & $1.0 \pm 0.0$ \\
\hline Mushrooms & $3.0(4)$ & $1.0 \pm 0.0$ \\
\hline Other hallucinogenic plants & $1.5(2)$ & $1.0 \pm 0.0$ \\
\hline 2C-B nexus & $0.7(1)$ & 1.0 \\
\hline Routes of consumption & & $\%(\mathrm{~N})^{\mathrm{b}}$ \\
\hline Sniff & & $81.5(110)$ \\
\hline Smoke & & $74.8(101)$ \\
\hline Oral & & $70.4(95)$ \\
\hline Inhaled & & $58.5(79)$ \\
\hline Injection & & $10.4(14)$ \\
\hline Anal & & $9.6(13)$ \\
\hline
\end{tabular}

${ }^{\mathrm{a}}$ Frequency of consumption ranged from 1 (occasionally during the last 12 months); 2 (once a month); 3 (sometimes a month); 4 (once a week); 5 (sometimes a week) and 6 (daily)

${ }^{\mathrm{b}} \mathrm{S}$ core for each route of consumption was calculated by summing the use of the route in each drug

a negative predictor of being in the PURD group (Table 3). The model correctly classified $73.4 \%$ of the cases (Table 4 ).

\section{Evolution of Immunological Status During the Follow-Up Year}

The results of the main effects of the linear mixed model for repeated measures did not show a significant difference between the PURD and PNURD in the percentage of $\mathrm{CD}_{4}$ $(F[1,209]=2.63, p=0.106)$. The covariates, number of ART changes and years since HIV diagnosis were marginally related to the participant's percentage of $\mathrm{CD}_{4}(\mathrm{~F}(1$, $209)=3.01, p=0.084$ and $\mathrm{F}(1,209)=3.08, \mathrm{p}=0.080$, respectively). Also, there was no within subject effects because there was no significant change in $\mathrm{CD}_{4}$ cell/ $/ \mathrm{mm}^{3}$ between the first and the last determination during the follow-up year $(F(1,209)=0.2, p=0.138)$. Nevertheless, after controlling the effect of the covariates, the interaction between group membership and the change in the percentage of $\mathrm{CD}_{4}$ cells $/ \mathrm{mm}^{3}$ during the follow-up year was marginally significant $(F(1,209)=3.56, p=0.060)($ Fig. 3) .

Moreover, the results did not show a significant main effect in the percentage of $\mathrm{CD}_{8}$ cells $/ \mathrm{mm}^{3}$ between the PURD and PNURD $(F(1,188)=0.26, p=0.609)$. Also, none of the covariates showed significant effects in the $\mathrm{CD}_{8}$ cells $/ \mathrm{mm}^{3}$ of the participants. Likewise, there was no within subject effects because there was no significant change in percentage of $\mathrm{CD}_{8}$ cells $/ \mathrm{mm}^{3}$ during the follow-up year $(F(1,188)=2.23, p=0.137)$. Nevertheless, after controlling for the effect of covariates, there 
Table 3 Logistic regression analysis of variables related to recreational drug use

\begin{tabular}{|c|c|c|c|c|c|}
\hline Parameter & $\beta$ & SE $\beta$ & $\begin{array}{l}\text { Wald's } \chi^{2} \\
(d f)\end{array}$ & $p$ & $\begin{array}{l}\mathrm{e}^{\beta} \text { (odds ratio) } \\
{[95 \% \mathrm{CI}]}\end{array}$ \\
\hline Constant & -1.03 & 1.35 & $0.59(1)$ & 0.355 & NA \\
\hline MSM (vs. HTX) & 1.42 & 0.66 & $4.68(1)$ & 0.031 & $4.14[1.14,5.19]$ \\
\hline STIs in the previous year (vs. no) & 1.39 & 0.36 & $14.76(1)$ & $<0.0001$ & $4.00[1.97,8.13]$ \\
\hline Current smoker (vs. no) & 1.00 & 0.33 & $9.50(1)$ & 0.002 & $2.74[1.44,5.19]$ \\
\hline Frequency of alcohol consumption ${ }^{a}$ & 0.18 & 0.09 & $3.59(1)$ & 0.058 & $1.19[0.99,1.44]$ \\
\hline Age & -0.05 & 0.02 & $7.65(1)$ & 0.006 & $0.94[0.91,0.98]$ \\
\hline Previous clinical conditions (vs. no) & -0.34 & 0.39 & $0.74(1)$ & 0.390 & $0.71[0.33,1.54]$ \\
\hline Income $^{b}$ & 0.15 & 0.25 & $0.36(1)$ & 0.548 & $1.16[0.71,1.91]$ \\
\hline Education level $^{\mathrm{c}}$ & 0.05 & 0.25 & $0.04(1)$ & 0.842 & $1.05[0.64,1.73]$ \\
\hline Working (vs. no working) & 0.39 & 0.42 & $0.85(1)$ & 0.356 & $1.48[0.64,3.39]$ \\
\hline $\begin{array}{l}\text { Transmission through sexual inter- } \\
\text { course (vs. other routes) }\end{array}$ & -0.16 & 0.47 & $0.12(1)$ & 0.731 & $0.85[0.34,2.13]$ \\
\hline Years since HIV diagnosis & 0.00 & 0.03 & $0.03(1)$ & 0.870 & $1.00[0.95,1.06]$ \\
\hline Model fit & & & & & \\
\hline
\end{tabular}

NA not applicable, MSM men who have sex with men, HTX heterosexual, STIs sexually transmitted infections

${ }^{a}$ Frequency of alcohol consumption responses ranged from 1 (never); 2 (sometimes a year); 3 (once a month); 4 (sometimes a month); 5 (once a week); 6 (sometimes a week) and 7 (daily)

${ }^{\mathrm{b}}$ Monthly income responses ranged from 1 (none); 2 ( $\left.\leq 1000 €\right) ; 3(1001-2000 €) ; 4(2001-6000 €)$ and 5 $(>6001 €)$

${ }^{\mathrm{c}}$ Level of education responses ranged from 1 (no studies); 2 (primary); 3 (secondary) and 4 (university degree)
Table 4 Classification table: the observed and predicted frequencies of predictors of drug use estimated by logistic regression

\begin{tabular}{llll}
\hline & \multicolumn{2}{l}{ Predicted } & \% Corrected $^{\text {a }}$ \\
\cline { 2 - 3 } Observed & PURD & PNURD & \\
\hline PURD & 86 & 28 & 75.4 \\
PNURD & 33 & 82 & 71.3 \\
Overall \% correct & & & 73.4 \\
\hline
\end{tabular}

PURD people using recreational drugs, PNURD people not using recreational drugs

${ }^{\text {a }}$ Sensitivity $=86 /(86+28)=75.4 \%$.

Specificity $=82 /$

$(33+82)=71.3 \%$. False positive $=33 /(33+86)=27.7 \%$. False negative $=28(28+82)=25.4 \%$

was a significant interaction between group membership and the percentage of $\mathrm{CD}_{8}$ cells $/ \mathrm{mm}^{3}(F(1,188)=4.52$, $p=0.035)$. While the percentage of $\mathrm{CD}_{8}$ cells $/ \mathrm{mm}^{3}$ decreased amongst the PNURD, it remained stable in PURD (Fig. 4).

Finally, we did not find the main effects between and within subject because there were no significant differences between the PURD and PNURD in the $\mathrm{CD}_{4} / \mathrm{CD}_{8}$ ratio $(F(1,188)=0.45, p=0.503)$, or in the change in ratio during the follow-up year $(F(1,188)=0.03, p=0.954)$. Also, none of the covariates showed significant effects in the $\mathrm{CD}_{4} / \mathrm{CD}_{8}$ ratio of the participants. However, we found a significant interaction between intragroup membership and the $\mathrm{CD}_{4} / \mathrm{CD}_{8}$ ratio $(F(1,188)=3.84, p=0.050)$. While the $\mathrm{CD}_{4} / \mathrm{CD}_{8}$ ratio increased amongst the PNURD during the follow-up year, it decreased amongst the PURD (Fig. 5).

Table 5 presents the marginal means, standard errors and confidence intervals in the immunological variables in both groups.

\section{Differences in Health Outcomes and Use of Healthcare Services and Resources}

Both the PURD and PNURD maintained undetectable viral loads throughout the follow-up year without group differences. However, there was a higher percentage of PURD than PNURD who had experienced changes in their ART regimen during the follow-up year, mainly because of adverse effects and drug-drug interactions. Moreover, a marginally higher number of PURD than PNURD presented non-AIDS related events.

We observed a higher proportion and number of analytical tests performed amongst the PURD. A higher percentage of PURD visited emergency units and a lower percentage visited specialised care units. In addition, PURD participants presented lower scores in the two measures of ART adherence (i.e., self-report measured through a validated questionnaire and multi-interval adherence calculated through 
Fig. 3 Evolution of $\mathrm{CD}_{4} \%$ cells $/ \mathrm{mm}^{3}$ in the follow-up year. Note The y axis does not start from 0; this is to facilitate visualisation of the graph. $P U R D$ people using recreational drugs, $P N U R D$ people not using recreational drugs
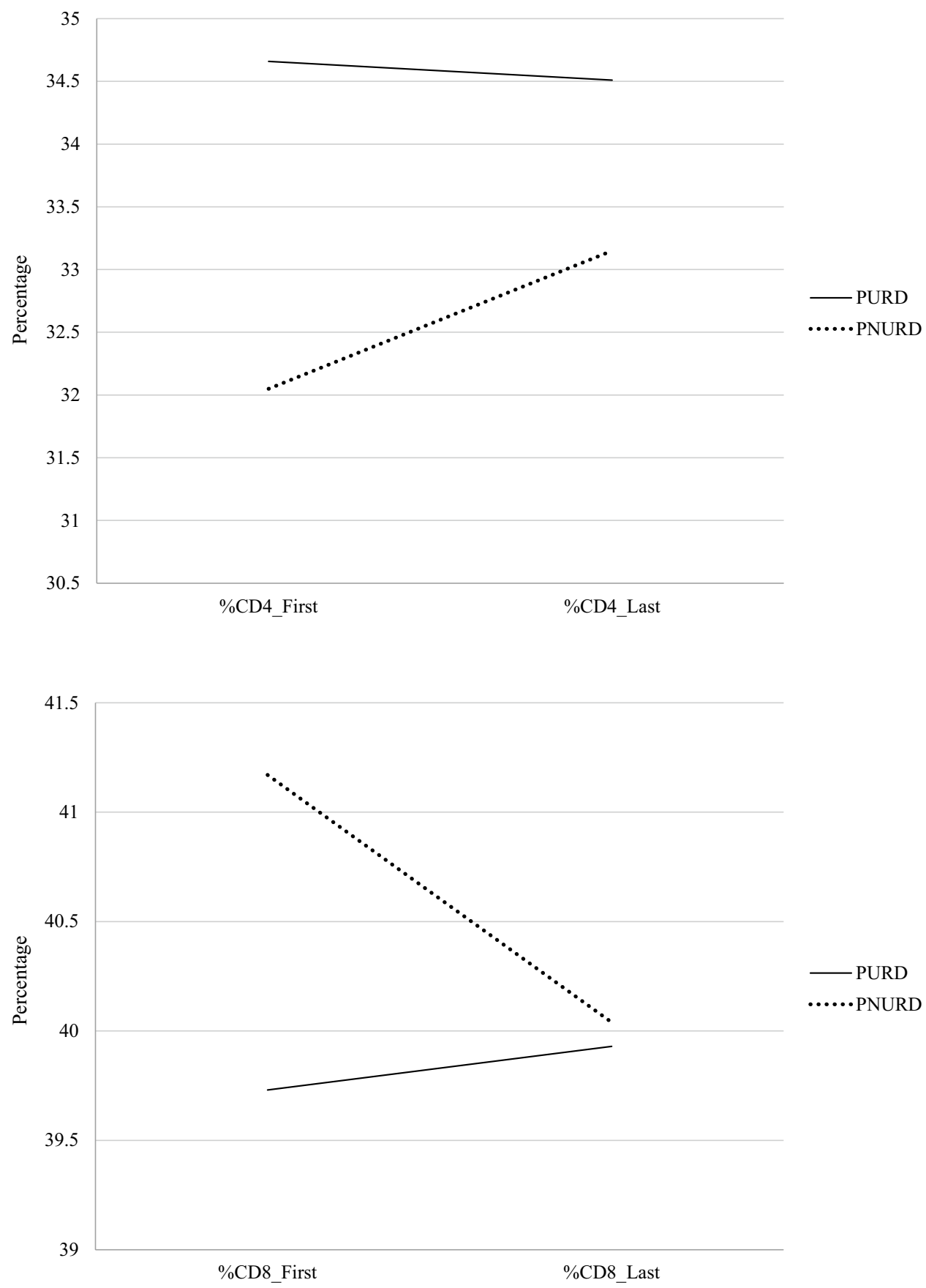

Fig. 4 Evolution of $\mathrm{CD}_{8} \%$ cells $/ \mathrm{mm}^{3}$ in the follow-up year. Note The y axis does not start from 0 ; this is to facilitate visualisation of the graph. $P U R D$ people using recreational drugs, $P N U R D$ people not using recreational drugs pharmacy refills) than PNURD. Finally, the PURD presented poorer psychological well-being than the PNURD (Table 6).

\section{Discussion}

To the best of our knowledge, the present study is the first to evaluate the association between RDU and clinical variables of physical and psychological health, as well as variables of health economy, in a PLHIV cohort in Spain.
First, we examined the variables associated with RDU in PLHIV. We found that the strongest associations were: being MSM, having suffered STIs during the previous year, and being a regular smoker. The frequency of consumption of alcoholic beverages and being younger were also associated with RDU, albeit at a lower intensity. These results confirm the findings of other studies, where a higher prevalence of RDU amongst those of a younger age $[3,59,60]$ and a higher incidence of STIs in the HIV population [3,61-63] were found. Legal drugs such as 
Fig. 5 Evolution of the $\mathrm{CD}_{4} /$ $\mathrm{CD}_{8}$ ratio in the follow-up year. Note The y axis does not from 0 ; this is to facilitate visualisation of the graph. PURD people using recreational drugs, $P N U R D$ people not using recreational drugs

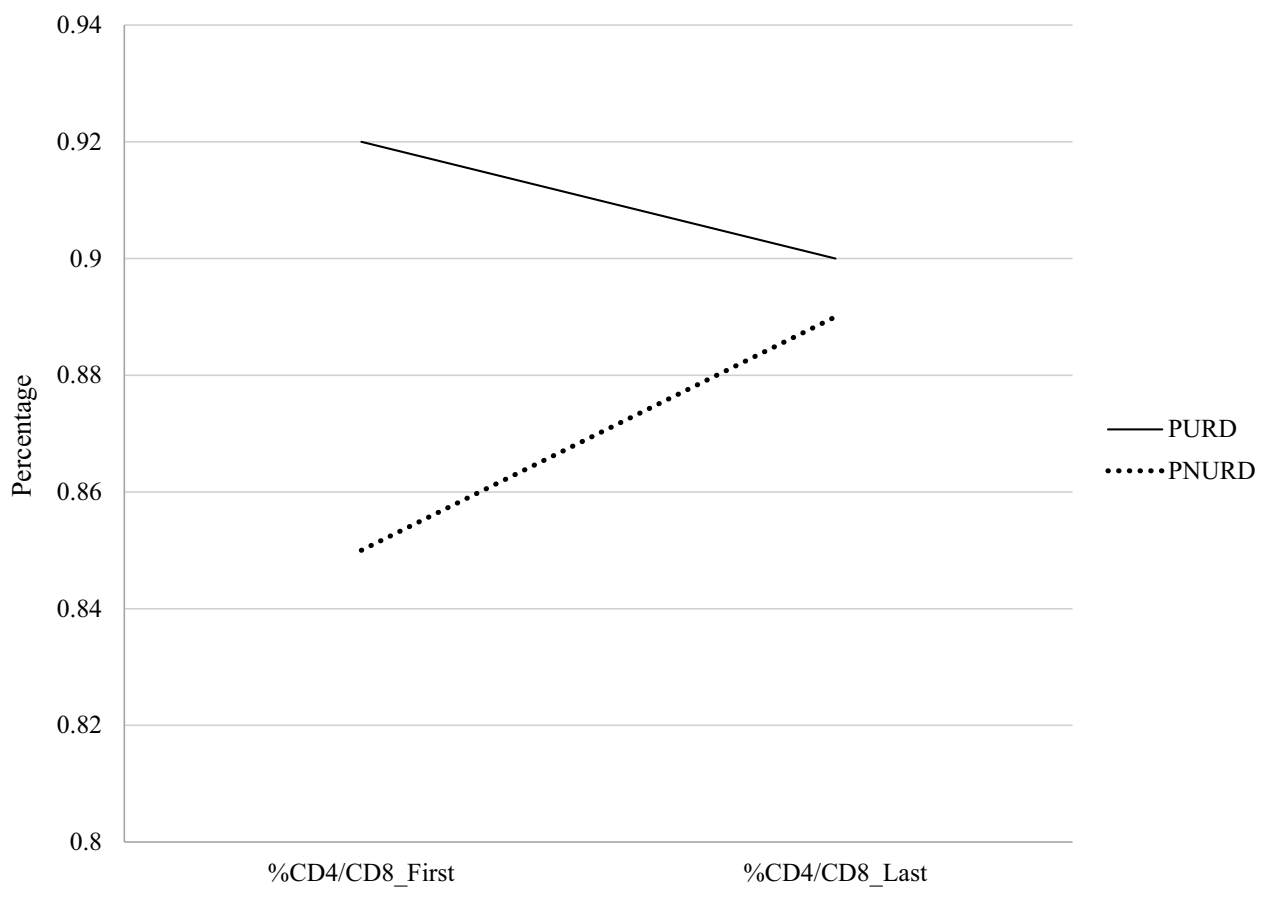

alcohol and tobacco are the most commonly used drugs amongst MSM, according to the European MSM Internet Survey [8]. Most studies include alcohol and tobacco when studying the effects of drugs, and show that a high percentage of patients consume recreational drugs and alcohol combined with tobacco [43, 64]. Therefore, it makes sense to think that alcohol or tobacco use is related to RDU.

Following this, we examined differences in health outcomes as a function of using recreational drugs or not. The

Table 5 Marginal means, standard errors, and 95\% confidence intervals in the dependent variables in PURD and PNURD

\begin{tabular}{llllll}
\hline Dependent & \multirow{2}{*}{$\begin{array}{l}\text { Group (Fac- } \\
\text { variable }\end{array}$} & Measure & \multicolumn{3}{l}{ Statistics } \\
\cline { 4 - 6 } & & & $M$ & $S E$ & $95 \% \mathrm{CI}$ \\
\hline $\mathrm{CD}_{4}$ cells/ & PURD & Baseline & 34.66 & 0.91 & $32.86,36.47$ \\
$\mathrm{~mm}^{3}(\%)$ & & & & & \\
& PNURD & & 32.05 & 0.86 & $30.35,3376$ \\
& PURD & Last & 34.51 & 0.86 & $32.80,36.22$ \\
& PNURD & & 33.15 & 0.82 & $31.53,34.77$ \\
$\mathrm{CD}_{8}$ cells/ & PURD & Baseline & 39.73 & 1.11 & $37.54,41.93$ \\
$\mathrm{~mm}^{3}(\%)$ & & & & & \\
& PNURD & & 41.17 & 1.07 & $39.04,43.29$ \\
& PURD & Last & 39.93 & 1.01 & $37.93,41.93$ \\
& PNURD & & 40.04 & 0.98 & $38.11,41.97$ \\
$\mathrm{CD}_{4} / \mathrm{CD}_{8}$ ratio & PURD & Baseline & 0.92 & 0.44 & $0.84,1.01$ \\
& PNURD & & 0.85 & 0.04 & $0.77,0.93$ \\
& PURD & Last & 0.90 & 0.04 & $0.82,0.98$ \\
& PNURD & & 0.89 & 0.04 & $0.81,0.97$ \\
\hline
\end{tabular}

PURD people using recreational drugs, $P N U R D$ people not using recreational drugs linear mixed model results did not find significant differences in the percentage of $\mathrm{CD}_{4}, \mathrm{CD}_{8}$, or $\mathrm{CD}_{4} / \mathrm{CD}_{8}$ between the PURD and PNURD. The epidemiological and clinical variables that characterised the PURDs, such as being HIV positive for a shorter time, being younger, or having fewer clinical antecedents [3], might have influenced the lack of difference in the cross-sectional measures between both groups. The results did not show any differences withinsubjects because there were no significant changes in the immune parameters during the follow-up year. However, we found significant interaction effects between the evolution of immune parameters in the follow-up period and group membership. While the PURD group experienced a decrease in the $\mathrm{CD}_{4} / \mathrm{CD}_{8}$ ratio throughout the follow-up, it increased in the PNURD group. This increase was associated with a decrease in the percentage of $\mathrm{CD}_{8}$ and an increase in the percentage of $\mathrm{CD}_{4}$ during the follow-up year in the PNURD group, whereas the PURD group remained stable both in the evolution of $\mathrm{CD}_{4}$ and $\mathrm{CD}_{8}$. We found the previous results controlling some covariates which the literature shows could influence immune parameters such as age, time since diagnosis, adherence level, and ART changes [29, 31-33]. However, our results should be interpreted with caution because other potential variables might influence the results. Furthermore, it has been suggested that being MSM could be associated with a change in the $\mathrm{CD}_{4} / \mathrm{CD}_{8}$ ratio because bacterial and viral agents responsible for STIs, which are more common among MSM, may increase immune activation and result in a continuous expansion of the $\mathrm{CD}_{8}$ population [32]. The $\mathrm{CD}_{4} / \mathrm{CD}_{8}$ ratio represents a predictor of age-related diseases and non-HIV-associated events (e.g., ischemic heart 
Table 6 Differences between PURD and PNURD in healthrelated variables

\begin{tabular}{|c|c|c|c|}
\hline HIV health-related variables & $\begin{array}{l}\text { PURD } \\
(n=135,51.3 \%)\end{array}$ & $\begin{array}{l}\text { PNURD } \\
(n=128,48.7 \%)\end{array}$ & $p$-value $\left(\chi^{2}\right)$ \\
\hline $\begin{array}{l}\text { Viral load undetectable in all tests of the follow-up } \\
\text { period, } \%(n)\end{array}$ & $83.0(112)$ & $84.4(108)$ & $0.868\left(\chi^{2}=0.09\right)$ \\
\hline Non-AIDS related events, $\%(n)$ & 30.4 (41) & $20.3(26)$ & $0.061\left(\chi^{2}=3.50\right)$ \\
\hline Opportunistic infection, \% (n) & $4.4(6)$ & $6.3(8)$ & $0.514\left(\chi^{2}=0.42\right)$ \\
\hline Adverse events, \% $(n)$ & $14.1(19)$ & $10.9(14)$ & $0.443\left(\chi^{2}=0.58\right)$ \\
\hline Change in ART regimen, $\%(n)$ & $35.6(48)$ & $21.9 \%(28)$ & $0.014\left(\chi^{2}=5.98\right)$ \\
\hline Resistance tests, \% ( $n)$ & $3(4)$ & $3.9(5)$ & $0.674\left(\chi^{2}=0.17\right)$ \\
\hline \multicolumn{4}{|l|}{ Use of healthcare resources } \\
\hline Diagnostic tests, \% $(n)$ & $64.4(87)$ & $64.8(83)$ & $0.946\left(\chi^{2}=0.00\right)$ \\
\hline Radiological tests, \% ( $n)$ & $45.9(62)$ & $55.5(71)$ & $0.122\left(\chi^{2}=2.39\right)$ \\
\hline Analytical tests, \% (n) & $26.7(36)$ & $12.5(16)$ & $0.004\left(\chi^{2}=8.31\right)$ \\
\hline Pathological anatomy tests, \% (n) & $9.6(13)$ & $13.3(17)$ & $0.352\left(\chi^{2}=0.86\right)$ \\
\hline Surgical procedure tests, $\%(n)$ & $0.7(1)$ & $3.9(5)$ & $0.086\left(\chi^{2}=2.95\right)$ \\
\hline Exploratory tests, \% (n) & 0 & $3.9(5)$ & NA \\
\hline Electromagnetic tests, \% $(n)$ & $4.4(6)$ & $7.8(10)$ & $0.253\left(\chi^{2}=1.30\right)$ \\
\hline Other tests $\%(n)$ & $3.7(5)$ & $6.3(8)$ & $0.341\left(\chi^{2}=0.90\right)$ \\
\hline \multicolumn{4}{|l|}{ Use of healthcare services } \\
\hline Primary care visits, \% (n) & $5.9(8)$ & $1.6(2)$ & $0.064\left(\chi^{2}=3.42\right)$ \\
\hline Specialised care visits, \% ( $n)$ & $83.7(113)$ & $91.4(117)$ & $0.059\left(\chi^{2}=3.55\right)$ \\
\hline Emergency room visits, \% (n) & $61.8(42)$ & $38.2(26)$ & $0.046\left(\chi^{2}=3.99\right)$ \\
\hline Hospitalisation, \% (n) & $3.7(5)$ & $6.3(8)$ & $0.341\left(\chi^{2}=0.90\right)$ \\
\hline \multicolumn{4}{|l|}{ ART adherence } \\
\hline Multi-interval adherence (pharmacy refill), $M \pm S D$ & $90.9 \pm 14.2$ & $94.5 \pm 9.2$ & $0.017(t=-2.40)$ \\
\hline Self-reported adherence (CEAT-HIV), $M \pm S D$ & $87.8 \pm 9.3$ & $90.6 \pm 6.7$ & $0.006(t=-2.74)$ \\
\hline Psychological well-being ${ }^{\mathrm{a}}, M \pm S D$ & $12.88 .1 \pm 6.3$ & $10.62 \pm 4.3$ & $0.0001(t=3.38)$ \\
\hline
\end{tabular}

PURD people using recreational drugs, PNURD people not using recreational drugs, $A R T$ antiretroviral treatment, $N A$ not applicable

${ }^{a}$ The scores ranged from 0 to 36 . Means and standard deviations were calculated using the number of patients with presence (yes) in the variable. All mean differences were also tested through non-parametric tests disease, stroke, and chronic kidney failure [65] and higher mortality [66]. Moreover, $\mathrm{CD}_{4} / \mathrm{CD}_{8}$ ratio recently has been shown to be a more sensitive immune prognostic marker of adverse outcomes than the $\mathrm{CD}_{4}$ cell count which frequently normalises with effective ART [32]. Thus, further longitudinal studies that analyse longer follow-up times and more potential covariates that the current research, should deepen the impact of the polyconsumption of recreational drugs on immune parameters.

Additionally, we found that the adherence rate measured by two indirect evaluation methods was lower in the PURD group. Our results are consistent with evidence showing that people who use drugs are more likely to experience adherence problems [9, 26, 34, 35]. However, adherence does not seem to be determinant in the changes we found in the immune markers' evolution, in agreement with other studies [33]. On the contrary, previous studies found that adherence levels influence the decline of these markers [29, 31]. However, these studies were conducted prior to current ART therapy which determines the less strict adherence to cut-off points [44]. Thus, our sample's adherence level does not appear to have impacted their virological suppression because a small percentage of participants presented detectable viral loads. In this regard, some studies claim that RDU in PLHIV does not negatively impact the viral load [42, 43], and argue that the most influential aspect in terms of health impact is not specifically drug use itself, but the degree of dependence on drug use. It should be noted that although a small percentage presented a detectable viral load (about 15\% of patients), the impact could be transcendent at the level of HIV transmissibility, especially in the MSM group, who are involved in more extreme sexual practices (i.e., chemsex). It is to be hoped that, over time, the difference between the groups will be more pronounced and may have a greater impact on patients' viral load. According to published studies, adherence remains at more stable levels for the first 24 months of treatment and decreases by $5 \%$ 
every 6 months [42]. Adherence to ART is paramount to controlling HIV infection, and is associated with positive clinical outcomes [67, 68].

The present study also found that the PURD had experienced more ART treatment changes during the follow-up year. Moreover, the linear mixed model results found a marginal association with it and participant's percentage of $\mathrm{CD}_{4}$. According to published studies, ART changes are a predictor of viral suppression failure [69]. The side effects and toxicity associated with treatment and interactions were the main causes of ART changes. Some studies have found a high prevalence of interactions between ART and recreational drugs, in some cases with severe consequences [26]. Thus, close attention should be paid to adequately addressing factors associated with ART changes.

Likewise, we found that the PURD had worse psychological health than the PNURD. Anxiety and depression are two of the most prevalent symptoms amongst PLHIV [48, 49], and both may be at the root and the result of problematic drug use [70]. Drug use is also related to dependence. This is a complex relationship that can cause mental health problems, stigmatisation, and sexual acceptance, amongst others [71].

In our study, a higher proportion of patients visiting emergency units was found amongst the PURDs (1.6 times higher than the PNURD), which did not include patients with severe mental morbidity - according to published studies, this seems to be a determinant of hospital morbidity [51, $72,73]$. We also found a high frequency of emergency visits (175 visits per 100 patients per year), although there were no differences between the PURD and PNURD. This might be explained by the fact that the PNURD had longer medical histories. According to a meta-analysis [53], the combined rate in the studies covered was 151 emergency visits per 100 people per year in the general drug-using population. Our study reflects a high demand for emergency care in the drug consuming PLHIV population. Predictors of risk of hospital emergency services by drug-consuming patients include patients diagnosed with HIV, mental health problems, and polyconsumption [14, 51, 74-79].

Our study has some limitations. Because it is observational, the relationships may be influenced by confounding variables. Although we use a longitudinal design, our findings are limited by the short follow-up period. Furthermore, because of the retrospective study design, we could not collect relevant data that are potentially related to our findings, such as the frequency and number of drugs consumed throughout the follow-up period. Also, some of the data presented come from a self-reported questionnaire, and there was no way to verify the veracity of the information. It is possible that respondents may have attenuated their answers with regard to drug use, which would have led to information bias. However, our results should be interpreted in light of the extensive research conducted. We carried out various types of triangulation, obtaining different types of data through different methodologies. This will have given our conclusions greater validity.

\section{Conclusions}

According to our results, RDU in PLHIV who are in ART treatment has clinical implications for health-related variables, such as immune status, adherence to ART treatment, psychological well-being, and the use of healthcare resources.

The long-term impact of using recreational drugs on PLHIV's health could be more extensive than our results suggest. Patients belonging to the PURD group presented better health status than the PNURD group, who had a higher rate of associated comorbidities. Thus, interventions are needed to reduce the negative impact of drug use on health. These interventions should provide patients with adequate information on the potential risks related to RDU: drug-drug interactions, adverse effects, and the impact on physical and psychological health. Moreover, appropriate ART is necessary for patients who use drugs, so that changes due to interactions and side effects that may produce resistance and therapeutic failure can be avoided. These actions should preferably target MSMs with HIV and young people who have previously experienced STIs.

Acknowledgements This paper has been researched and written by the authors on behalf of the Study Group on the Use of Recreational Illicit Drugs Amongst PLHIV in Spain: Castro, V. (Hospital de la Marina Baixa de Villajoyosa, Universidad de Granada); Leal, L., Laguno, M., Martínez-Rebollar, M. (Hospital Clínic-IDIBAPS, Universidad de Barcelona); Casado, JL., Rojo, AM., Vizcarra, P. (Hospital Ramón y Cajal de Madrid); Garin, N., Aguilera, V., Saavedra, M., Gras, L., Gutierrez, M., Mateo, G. (Hospital de la Santa Creu i Sant Pau), Jaén, A. (Fundació Docència i Recerca MutuaTerrassa, University of Barcelona); Fuster-RuizdeApodaca, M. J. (SEISIDA). We thank the collaborating healthcare providers at the recruitment sites Hospital Clínic and Hospital de la Santa Creu i Sant Pau, Barcelona; Hospital Ramón y Cajal, Madrid; and Hospital de la Marina Baixa, Villajoyosa. This paper is part of the doctoral thesis of Vanesa María Castro Granell, who is on the Doctoral Program in Pharmacy, Granada University, Spain.

Author Contributions VC and MJF-RdA were the main analysts and writers of the manuscript. AJ contributed to the design of the research, data analysis, and improvements in the writing of the paper. NG, JC, LL contributed to the design and development of the research, reviewing other studies and improving the writing of the paper. All authors read and approved the final manuscript.

Funding This study was funded by ViiV Healthcare.

Data Availability Data are available from https://doi.org/10.6084/m9. figshare.13090142.v1 


\section{Declarations}

Conflict of interest This study was funded by ViiV Healthcare (www. viivhealthcare.com). ViiV was involved in the study design and preparation of the manuscript, but did not influence the data collection and analysis or the decision to publish. All listed authors meet the criteria for authorship set forth by the International Committee of Medical Journal Editors. All authors had full access to the data and all are responsible for the veracity and completeness of the reported data. SCG is employed full-time in ViiV Healthcare. MJF-RdA, and AJ, are members of the Spanish Interdisciplinary Aids Society (SEISIDA) Executive Board. SEISIDA has received grants from MSD, ViiV, Janssen, and Gilead. MJF-RdA has provided consultancy services to ViiV, Gilead, MSD, and Janssen, and has received payments for lectures or educational presentations from MSD, Gilead, Janssen, and ViiV. JC has provided consultancy services to ViiV, Gilead, and Janssen, and has received payments for lectures or educational presentations from MSD, Gilead, Janssen, and ViiV. NG has received payments for lectures or educational presentations from ViiV. LL has provided consultancy services and has received payments for lectures or educational presentations from Gilead. These interests do not alter our adherence to AIDS and behaviour policies on sharing data and materials.

Ethical Approval This retrospective chart review study involving human participants was in accordance with the ethical standards of the institutional and national research committee and with the 1964 Helsinki Declaration and its later amendments or comparable ethical standards. The Ethics Committee of the Hospital Clínico of Valencia approved this study.

Informed Consent The participants were informed of the objectives of the study, and written informed consent was obtained.

Open Access This article is licensed under a Creative Commons Attribution 4.0 International License, which permits use, sharing, adaptation, distribution and reproduction in any medium or format, as long as you give appropriate credit to the original author(s) and the source, provide a link to the Creative Commons licence, and indicate if changes were made. The images or other third party material in this article are included in the article's Creative Commons licence, unless indicated otherwise in a credit line to the material. If material is not included in the article's Creative Commons licence and your intended use is not permitted by statutory regulation or exceeds the permitted use, you will need to obtain permission directly from the copyright holder. To view a copy of this licence, visit http://creativecommons.org/licenses/by/4.0/.

\section{References}

1. Rodger AJ, Lodwick R, Schechter M, et al. Mortality in well controlled HIV in the continuous antiretroviral therapy arms of the SMART and ESPRIT trials compared with the general population. AIDS. 2013;27(6):973-9. https://doi.org/10.1097/QAD.0b013 e32835cae9c.

2. Fuster-RuizdeApodaca MJ, Castro-Granell V, Laguía A, Jaén Á, Cenoz S, Galindo MJ. Drug use and antiretroviral therapy (ART) interactions: a qualitative study to explore the knowledge, beliefs, adherence, and quality of life of people living with HIV taking ART and illicit drugs. AIDS Res Ther. 2020;17(1):24. https://doi. org/10.1186/s12981-020-00279-y.

3. Fuster-RuizdeApodaca M, Castro-Granell V, Garin N, et al. Prevalence and patterns of illicit drug use in people living with HIV in Spain: a cross-sectional study. PLoS ONE. 2019;14(6):1-18. https://doi.org/10.1371/journal.pone.0211252.

4. Sánchez PL. Situación actual y evolución de los consumos de drogas ilícitas en España. Trastor Adict. 2001;3(2):85-94.

5. Coll J, Fumaz CR. Drogas recreativas y sexo en hombres que tienen sexo con hombres: chemsex. Riesgos, problemas de salud asociados a su consumo, factores emocionales y estrategias de intervención. Rev Enf Emerg. 2016;15(2):77-84.

6. Barrio G, Bravo MJ, Brugal MT, et al. Harm reduction interventions for drug injectors or heroin users in Spain: expanding coverage as the storm abates. Addiction. 2012;107(6):1111-22. https:// doi.org/10.1111/j.1360-0443.2011.03759.x.

7. World Health Organisation. Consolidated guidelines on HIV prevention, diagnosis, treatment and care for key populations. Geneva: WHO; 2014.

8. EMIS Network. EMIS 2010: the European men-who-have-sexwith-men internet survey. Findings from 38 countries. Stockholm: European Centre for Disease Prevention and Control; 2013. http:// www.emis-project.eu.

9. Daskalopoulou M, Rodger A, Phillips AN, et al. Recreational drug use, polydrug use, and sexual behaviour in HIV-diagnosed men who have sex with men in the UK: results from the cross-sectional ASTRA study. Lancet. 2014;3018(14):1-10. https://doi.org/10. 1016/S2352-3018(14)70001-3.

10. González-Baeza A, Dolengevich-Segal H, Pérez-Valero I, et al. Sexualized drug use (chemsex) is associated with high-risk sexual behaviours and sexually transmitted infections in HIV-positive men who have sex with men: data from the U-SEX GESIDA 9416 Study. AIDS Patient Care STDS. 2018;32(3):112-8. https://doi. org/10.1089/apc.2017.0263.

11. Garin N, Velasco C, De Pourcq JT, et al. Recreational drug use among individuals living with HIV in Europe: review of the prevalence, comparison with the general population and HIV guidelines recommendations. Front Microbiol. 2015;6:690. https://doi. org/10.3389/fmicb.2015.00690.

12. Hickson F, Bonell C, Weatherburn P, Reid D. Illicit drug use among men who have sex with men in England and Wales. Addict Res Theory. 2010;18(1):14-22. https://doi.org/10.3109/16066 350902770433.

13. Grov C, Kelly BC, Parsons JT. Polydrug use among club-going young adults recruited through time-space sampling. Subst Use Misuse. 2009;44(6):848-64. https://doi.org/10.1080/1082608080 2484702.

14. Palepu A, Tyndall MW, Leon $\mathrm{H}$, et al. Hospital utilization and costs in a cohort of injection drug users. CMAJ. 2001;165(4):415-20.

15. Kendall CE, Boucher LM, Mark AE, et al. A cohort study examining emergency department visits and hospital admissions among people who use drugs in Ottawa, Canada. Harm Reduct J. 2017;14(1):16. https://doi.org/10.1186/s12954-017-0143-4 ((Erratum in: Harm Reduct J. 2017;14(1):42)).

16. Takahashi TA, Merrill JO, Boyko EJ, Bradley KA. Type and location of injection drug use-related soft tissue infections predict hospitalisation. J Urban Health. 2003;80(1):127-36. https://doi. org/10.1093/jurban/jtg127.

17. Butler AJ, Rehm J, Fischer B. Health outcomes associated with crack-cocaine use: systematic review and meta-analyses. Drug Alcohol Depend. 2017;180:401-16. https://doi.org/10.1016/j. drugalcdep.2017.08.036.

18. Folch C, Esteve A, Zaragoza K, Muñoz R, Casabona J. Correlates of intensive alcohol and drug use in men who have sex with men in Catalonia. Spain Eur J Public Health. 2010;20(2):139-45. https://doi.org/10.1093/eurpub/ckp091.

19. Centre d'Estudis Epidemiològics sobre les infeccions de Transmissió Sexual i SIDA de Catalunya (CEEISCAT). Vigilància 
epidemiològica de les infeccions de transmissió sexual a Catalunya, 2019.

20. Pufall EL, Kall M, Shahmanesh M, et al. Sexualized drug use ('chemsex') and high-risk sexual behaviours in HIV-positive men who have sex with men. HIV Med. 2018;19(4):261-70. https:// doi.org/10.1111/hiv.12574.

21. Buchacz K, McFarland W, Kellogg TA, et al. Amphetamine use is associated with increased HIV incidence among men who have sex with men in San Francisco. AIDS. 2005;19(13):1423-4. https://doi.org/10.1097/01.aids.0000180794.27896.fb.

22. Mansergh G, Purcell DW, Stall R, et al. CDC consultation on methamphetamine use and sexual risk behaviour for HIV/ STD infection: summary and suggestions. Public Health Rep. 2006;121(2):127-32. https://doi.org/10.1177/003335490612100 205.

23. Carey JW, Mejia R, Bingham T, et al. Drug use, high-risk sex behaviours, and increased risk for recent HIV infection among men who have sex with men in Chicago and Los Angeles. AIDS Behav. 2009;13(6):1084-96. https://doi.org/10.1007/ s10461-008-9403-3.

24. Schwarcz S, Scheer S, McFarland W, et al. Prevalence of HIV infection and predictors of high-transmission sexual risk behaviours among men who have sex with men. Am J Public Health. 2007;97(6):1067-75. https://doi.org/10.2105/AJPH.2005.072249.

25. Li J, McDaid LM. Alcohol and drug use during unprotected anal intercourse among gay and bisexual men in Scotland: what are the implications for HIV prevention? Sex Transm Infect. 2014;90(2):125-32. https://doi.org/10.1136/sextr ans-2013-051195.

26. Garin N, Zurita B, Velasco C, Feliu A, Gutierrez M, Mangues MA. Prevalence and clinical impact of recreational drug consumption in people living with HIV on treatment: a cross-sectional study. BMJ Open. 2017;7(1):e014105. https://doi.org/10.1136/ bmjopen-2016-014105.

27. Chao C, Jacobson LP, Tashkin D, et al. Recreational drug use and T lymphocyte subpopulations in HIV-uninfected and HIV-infected men. Drug Alcohol Depend. 2008;94(1-3):165-71. https://doi. org/10.1016/j.drugalcdep.2007.11.010.

28. Mor Z, Turner D, Livnat Y, et al. Recreational drug and excessive alcohol use among HIV-infected men who have sex with men in Central Israel. BMC Public Health. 2019;19:1360. https://doi.org/ 10.1186/s12889-019-7747-4.

29. Lucas GM, Cheever LW, Chaisson RE, Moore RD. Detrimental effects of continued illicit drug use on the treatment of HIV-1 infection. J Acquir Immune Defic Syndr. 2001;27(3):251-9. https://doi.org/10.1097/00126334-200107010-00006.

30. Lucas GM, Gebo KA, Chaisson RE, Moore RD. Longitudinal assessment of the effects of drug and alcohol abuse on HIV-1 treatment outcomes in an urban clinic. AIDS. 2002;16(5):767-74. https://doi.org/10.1097/00002030-200203290-00012.

31. Cofrancesco J Jr, Scherzer R, Tien PC, et al. Illicit drug use and HIV treatment outcomes in a US cohort. AIDS. 2008;22(3):35765. https://doi.org/10.1097/QAD.0b013e3282f3cc21.

32. Serrano-Villar S, Martínez-Sanz J, Ron R, et al. Effects of firstline antiretroviral therapy on the CD4/CD8 ratio and CD8 cell counts in CoRIS: a prospective multicentre cohort study. Lancet HIV. 2020;7(8):e565-73. https://doi.org/10.1016/S2352-3018(20) 30202-2.

33. Montarroyos UR, Miranda-Filho DB, César CC, et al. Factors related to changes in CD4+ T-cell counts over time in patients living with HIV/AIDS: a multilevel analysis. PLoS ONE. 2014;9(2):e84276. https://doi.org/10.1371/journal.pone.0084276.

34. Moore DJ, Blackstone K, Woods SP, et al. Methamphetamine use and neuropsychiatric factors are associated with antiretroviral non-adherence. AIDS Care. 2012;24(12):1504-13. https://doi.org/ $10.1080 / 09540121.2012 .672718$
35. Parsons JT, Kowalczyk WJ, Botsko M, Tomassilli J, Golub SA. Aggregate versus day level association between methamphetamine use and HIV medication non-adherence among gay and bisexual men. AIDS Behav. 2013;17(4):1478-87. https://doi.org/10.1007/ s10461-013-0463-7.

36. Halkitis P, Palamar J, Mukherjee P. Analysis of HIV medication adherence in relation to person and treatment characteristics using hierarchical linear modelling. AIDS Patient Care STDS. 2008;22(4):323-35. https://doi.org/10.1089/apc.2007.0122.

37. Peretti-Watel P, Spire B, Lert F, Obadia Y, VESPA Group. Drug use patterns and adherence to treatment among HIV-positive patients: evidence from a large sample of French outpatients (ANRS-EN12-VESPA 2003) Patrick. Drug Alcohol Depend. 2006;82 (Suppl1):S71-9. https://doi.org/10.1016/s03768716(06)80012-8

38. Kalichman SC, Rompa D. HIV treatment adherence and unprotected sex practices in people receiving antiretroviral therapy. Sex Transm Infect. 2003;79(1):59-61. https://doi.org/10.1136/ sti.79.1.59.

39. Catz SL, Kelly JA, Bogart LM, Benotsch EG, McAuliffe TL. Patterns, correlates, and barriers to medication adherence among persons prescribed new treatments for HIV disease. Health Psychol. 2000;19(2):124-33.

40. Mohammed H, Kieltyka L, Richardson-Alston G, et al. Adherence to HAART among HIV-infected persons in rural Louisiana. AIDS Patient Care STDS. 2004;18(5):289-96. https://doi. org/10.1089/108729104323076025.

41. Martini M, Recchia E, Nasta P, et al. Illicit drug use: can it predict adherence to antiretroviral therapy? Eur J Epidemiol. 2004;19(6):585-7. https://doi.org/10.1023/b:ejep.0000032353. 03967.ef.

42. Malta M, Magnanini MMF, Strathdee SA, Bastos FI. Adherence to antiretroviral therapy among HIV-infected drug users: a meta-analysis. AIDS Behav. 2010;14(4):731-47. https://doi. org/10.1007/s10461-008-9489-7.

43. Ustinov A, Suvorova A, Belyakov A, et al. Psychiatric distress, drug use, and HIV viral load suppression in Russia. AIDS Behav. 2016;20(8):1603-8. https://doi.org/10.1007/ s10461-016-1297-x.

44. Bezabhe WM, Chalmers L, Bereznicki LR, Peterson GM. Adherence to antiretroviral therapy and virologic failure Bezabhe WM, Chalmers L, Bereznicki LR, Peterson GM. Adherence to antiretroviral therapy and virologic failure: a meta-analysis. Medicine (Baltimore). 2016;95(15):e3361. https://doi.org/10.1097/MD. 0000000000003361

45. Mohd Salleh NA, Richardson L, Kerr T, et al. A longitudinal analysis of daily pill burden and likelihood of optimal adherence to antiretroviral therapy among people living with HIV who use drugs. J Addict Med. 2018;12(4):308-14. https://doi.org/10.1097/ ADM.0000000000000403.

46. National Institute on Drug Abuse (NIDA). Common comorbidities with substance use disorders, 2018. https://www.drugabuse.gov.

47. Fletcher JB, Reback CJ. Depression mediates and moderates effects of methamphetamine use on sexual risk taking among treatment-seeking gay and bisexual men. Health Psychol. 2015;34(8):865-9. https://doi.org/10.1037/hea0000207.

48. Gordon A, Holmwood C. Drug and Alcohol Services South Australia et al. Primary Mental Health Care Australian Resource Centre, 2009. Comorbidity of mental disorders and substance use: a brief guide for the primary care clinician. Adelaide: Drug and Alcohol Services South Australia.

49. Pool E, Winston A, Bagkeris E, et al. High-risk behaviours, and their associations with mental health, adherence to antiretroviral therapy and HIV parameters, in HIV-positive men who have sex with men. HIV Med. 2019;20(2):131-6. https://doi.org/10.1111/ hiv. 12690 . 
50. Fendrich M, Avci O, Johnson TP, Mackesy-Amiti ME. Depression, substance use and HIV risk in a probability sample of men who have sex with men. Addict Behav. 2013;38(3):1715-8. https://doi.org/10.1016/j.addbeh.2012.09.005.

51. Graham K, Cheng J, Bernards S, Wells S, Rehm J, Kurdyak P. How much do mental health and substance use/addiction affect use of general medical services? Extent of use, reason for use, and associated costs. Can J Psychiatry. 2017;62(1):48-56. https://doi. org/10.1177/0706743716664884.

52. Choi SKY, Boyle E, Cairney J, et al. Impact of depression and recreational drug use on emergency department encounters and hospital admissions among people living with HIV in Ontario: a secondary analysis using the OHTN cohort study. PLoS ONE. 2018;13(4):e0195185. https://doi.org/10.1371/journal.pone.01951 85.

53. Lewer D, Freer J, King E, et al. Frequency of healthcare utilisation by adults who use illicit drugs: a systematic review and meta-analysis. Addiction. 2020;115(6):1011-23. https://doi.org/ 10.1111/add.14892.

54. HIV/AIDS Treatment Adherence, Health Outcomes and Cost Study Group. The HIV/AIDS treatment adherence, health outcomes and cost study: conceptual foundations and overview. AIDS Care. 2004;16(Suppl 1):S6-S21. https://doi.org/10.1080/09540 120412331315312

55. Langebeek N, Gisolf EH, Reiss P, et al. Predictors and correlates of adherence to combination antiretroviral therapy (ART) for chronic HIV infection: a meta-analysis. BMC Med. 2014;12:142. https://doi.org/10.1186/PREACCEPT-1453408941291432.

56. Remor E. Systematic review of the psychometric properties of the questionnaire to evaluate the adherence to HIV therapy (CEAT-VIH). Patient. 2013;6(2):61-73. https://doi.org/10.1007/ s40271-013-0009-0.

57. Goldberg DP, Hillier VF. A scaled version of the General Health Questionnaire. Psychol Med. 1979;9(1):139-45. https://doi.org/ 10.1017/s0033291700021644.

58. Muñoz-moreno JA, Fuster-RuizdeApodaca MJ, Fumaz CR, Molero F. Quejas cognitivas en personas con infección por el virus de la inmunodeficiencia humana en España: prevalencia y variables relacionadas. Med Clin (Barc). 2014;142(10):438-44. https://doi.org/10.1016/j.medcli.2013.02.037.

59. Grabovac I, Meilinger M, Schalk H, Leichsenring B, Dorner TE. Prevalence and associations of illicit drug and polydrug use in people living with HIV in Vienna. Sci Rep. 2018;8(1):8046. https://doi.org/10.1038/s41598-018-26413-5.

60. Stevens O, Moncrieff M, Gafos M. Chemsex-related drug use and its association with health outcomes in men who have sex with men: a cross-sectional analysis of Antidote clinic service data. Sex Transm Infect. 2020;96(2):124-30. https://doi.org/10.1136/sextr ans-2019-054040.

61. Dirección General de Salud Pública Calidad e Innovación. Vigilancia Epidemiológica del VIH y SIDA en España, actualización 30 de junio de 2017. Ministerio de Sanidad Servicios Sociales e Igualdad. 2016. https://www.msssi.gob.es/ciudadanos/ enfLesiones/enfTransmisibles/sida/vigilancia/ InformeVIH_ SIDA_2017_NOV2017.pdf.

62. Mor Z, Turner D, Livnat Y, Levy I. Recreational drug and excessive alcohol use among HIV-infected men who have sex with men in Central Israel. BMC Public Health. 2019;19(1):1360. https:// doi.org/10.1186/s12889-019-7747-4.

63. Hunter LJ, Dargan PI, Benzie A, White JA, Wood DM. Recreational drug use in men who have sex with men (MSM) attending UK sexual health services is significantly higher than in nonMSM. Postgrad Med J. 2014;90(1061):133-8. https://doi.org/10. 1136/postgradmedj-2012-131428.

64. Nolan S, Walley AY, Herren TC, et al. HIV-infected individuals who use alcohol and other drugs, and virologic suppression.
AIDS Care. 2017;29(9):1129-36. https://doi.org/10.1080/09540 121.2017.1327646.

65. Falp JB, Paniccia Cuoco F, Blancas Altabella D, et al. I/H-1.Relación cociente CD4/CD8 y tratamiento antirretroviral. Rev Clin Esp. 2014;214 (Espec Congr):1

66. Serrano-Villar S, Deeks SG. CD4/CD8 ratio: an emerging biomarker for HIV. Lancet HIV. 2015;2(3):e76-7. https://doi.org/10. 1016/S2352-3018(15)00018-1.

67. Bangsberg DR, Perry S, Charlebois ED, et al. Non-adherence to highly active antiretroviral therapy predicts progression to AIDS. AIDS. 2001;15(9):1181-3. https://doi.org/10.1097/00002030200106150-00015.

68. Simoni JM, Frick PA, Pantalone DW, Turner BJ. Antiretroviral adherence interventions: a review of current literature and ongoing studies. Top HIV Med. 2003;11(6):185-98.

69. Robbins GK, Johnson KL, Chang Y, et al. Predicting virologic failure in an HIV clinic. Clin Infect Dis. 2010;50(5):779-86. https://doi.org/10.1086/650537.

70. Lee JS, Bainter SA, Carrico AW, et al. Connecting the dots: a comparison of network analysis and exploratory factor analysis to examine psychosocial syndemic indicators among HIV-negative sexual minority men. J Behav Med. 2020;43(6):1026-40. https:// doi.org/10.1007/s10865-020-00148-z.

71. Torrens M, Mestre-Pinto J-I, Domingo-Salvany A. Comorbidity of substance use and mental disorders in Europe. Lisbon: EMCDDA; 2015.

72. Turner BJ, Laine C, Yang CP, Hauck WW. Effects of long-term, medically supervised, drug-free treatment and methadone maintenance treatment on drug users' emergency department use and hospitalization. Clin Infect Dis. 2003;37(s5):S457-63. https://doi. org/10.1086/377558.

73. Knowlton AR, Hoover DR, Chung SE, Celentano DD, Vlahov D, Latkin CA. Access to medical care and service utilisation among injection drug users with HIV/AIDS. Drug Alcohol Depend. 2001;64(1):55-62. https://doi.org/10.1016/s0376-8716(00) 00228-3.

74. Tran BX, Phan HT, Nguyen LH, et al. Economic vulnerability of methadone maintenance patients: implications for policies on co-payment services. Int J Drug Policy. 2016;31:131-7. https:// doi.org/10.1016/j.drugpo.2016.01.017.

75. Lloyd-Smith E, Wood E, Zhang R, Tyndall MW, Montaner JS, Kerr T. Risk factors for developing a cutaneous injection-related infection among injection drug users: a cohort study. BMC Public Health. 2008;8:405. https://doi.org/10.1186/1471-2458-8-405.

76. Schoenbaum EE, Lo Y, Floris-Moore M. Predictors of hospitalization for HIV-positive women and men drug users, 1996-2000. Public Health Rep. 2002;117(Suppl 1):S60-6.

77. Laine C, Hauck WW, Gourevitch MN, Rothman J, Cohen A, Turner BJ. Regular outpatient medical and drug abuse care and subsequent hospitalisation of persons who use illicit drugs. JAMA. 2001;285(18):2355-62. https://doi.org/10.1001/jama.285. 18.2355 .

78. Kelly E, McKetine R, McLaren J. Health service utilisation among regular methamphetamine users. NDARC Technical Report, 2005. Sydney: National Drug and Alcohol Research Centre.

79. Floris-Moore M, Lo Y, Klein RS, et al. Gender and hospitalization patterns among HIV-infected drug users before and after the availability of highly active antiretroviral therapy. J Acquir Immune Defic Syndr. 2003;34(3):331-7. https://doi.org/10.1097/00126 334-200311010-00012.

Publisher's Note Springer Nature remains neutral with regard to jurisdictional claims in published maps and institutional affiliations. 